\title{
Új hazai egészségmonitorozási koncepció
}

\author{
The concept of a new health monitoring system in Hungary
}

Szerzők: Varsányi Péter, $\square{ }^{a, b}{ }^{a}$ Tóth Gergely, ${ }^{a}$ Balku Eszter, ${ }^{a}$ Vitrai József ${ }^{a}$

a: Nemzeti Egészségfejlesztési Intézet, b: ELTE TáTK Szociológia Doktori Iskola

Összefoglaló: Háttér: Hosszabb ideje kiemelt politikai figyelem övezi az egészségügy területét, amelynek egyik oka, hogy a lakosság megromlott egészségéhez kapcsolódó költségek igen jelentős terhet rónak Magyarországra. Az informált döntéshozatalhoz, az erőforrások hatékony elosztásához, a megfelelő beavatkozások tervezéséhez ez idő szerint nem áll elegendő információ a döntéshozók és a szakemberek rendelkezésére. Célkitüzés: Ezt a problémát orvosolhatná a jelen közleményben felvázolt újfajta megközelítéseket ötvöző egészségmonitorozási rendszer. Ez öszszehangolná az egészségről és az azt meghatározó tényezőkről jelenleg folyó adatgyűjtéseket, kiegészítené azokat a gyermekek és felnőttek körében folyamatosan történő egészségfelmérésekkel, valamint egységes rendszerbe foglalná a meglévő elemzési kapacitásokat. Javasolt megoldás: Az eddigi gyakorlattól eltérően ebben a rendszerben egészséggel kapcsolatos adatokat nem csupán az egészségügyi ágazatból, hanem többek között a for-profit és non-profit szektorból, az egyén környezetéből, valamint közvetlenül az egyéntől is gyújtenének. A közlemény külön foglalkozik az egyének egészségmagatartásának és egészségkultúrájának rendszeres felméréséhez használható módszertannal, amely nagyban hozzájárulhat a magyar lakosság egészségének javítását célzó beavatkozások hatásosságának növeléséhez és értékeléséhez. Összegzés: Az itt bemutatott elképzelés a meglévő adatgyűjtések összehangolásával és korszerű technológiai és módszertani fejlesztéssel alapozná meg az egészséget érintő hazai informált döntéshozatalt.

Kulcsszavak: egészségmonitorozás; népegészségügy; egészségveszteség; informált döntéshozatal

Summary: Background: The awareness of politicians has risen in the field of health in the recent years in Hungary. One of its reasons is the significant burden caused by the poor health conditions of the population. At the moment, stakeholders and experts do not have enough information for the planning of proper interventions, for efficient capacity allocation and therefore, for informed decision making. Aim: The new health monitoring concept described in this paper aims to present a solution to this problem by synchronizing present data collections on health and health determinants, expanding them with continuous health surveys among children and adults as well as rearranging and harmonizing present analyzing capacities in a uniform system. In this new approach health related data would be collected not only in the health care sector, but, among others, also in the non-profit and for-profit sector, from the environment of individuals as well as directly from them. The paper pays special attention to continuous data collection about health behavior and health culture which can help to improve the efficiency and evaluation of interventions aiming to improve the health status of the population. Conclusions: The presented concept would establish informed decision making as regards health in Hungary by the harmonization of present data collections and by advanced technical and methodological development.

Keywords: health monitoring; public health; burden of diseases; DALY; informed decision making 


\section{A KIINDULÁSI PROBLÉMA?}

Köztudott, hogy nemcsak az ország fejlettségéhez viszonyítva, de abszolút mérőszámokkal kifejezve is rossz a magyar lakosság egészségi állapota, valamint, hogy ezen mutatókban még az EU újabb tagállamaitól is elmaradunk. Az talán kevésbé ismert, hogy a rossz egészségi állapot milyen sokféle területen jelent komoly terhet Magyarország számára (egészségügy, munkavállalás, rövidebb élettartam, stb.). Pontos adatok hiányában azonban csak becsülni lehet, hogy ezek a terhek mekkora, pénzben is kifejezhető egészségveszteséget okoznak Magyarországnak. ${ }^{1, i} \mathrm{Az}$ adatok hiányának legfőbb oka, hogy hazánkban nem működik olyan egészségmonitorozási rendszer, amely az egészség valamennyi összetevőjéről folyamatosan és egységes szemléletben gyűjitene és értékelne releváns adatokat². Ez azért is probléma, mivel ezek hiányában az elmúlt időszak kiemelt politikai figyelme ellenére sem lehet a szakterületen kellően alátámasztott, releváns információkon alapuló döntéseket hozni. Az utóbbi két évtizedben több hazai kísérlet is történt ennek a problémának a megoldására," a jelen közleményben részletezett koncepció azonban azoknál tágabban értelmezi az egészséget befolyásoló tényezőket és így az egészségmonitorozás szükséges feladatát is.

\section{MILYEN EGY IDEÁLIS MONITOROZÁSI REND- SZER?}

Egy ideális egészségmonitorozási rendszer a fentebb részletezett információhiányt és az abból fakadó problémákat képes orvosolni. Feladata, hogy összegyüjtsön valamennyi, az egészséggel kapcsolatos adatot és ezeket elemezze, értékelje, és az így létrejött információt visszaszolgáltassa, interpretálja az egészséggel kapcsolatba hozható társadalmi szereplőknek. ${ }^{3} \mathrm{Az}$ egészséggel kapcsolatos adatok gyors áttekintése és az információk megértésének könnyítése céljából többféle hazai és nemzetközi alkalmazás ismeretes. Hazai példaként említhető a Dr.Infó, a Nemzeti Egészségfejlesztési Intézet honlapján elérhető Halálozási adatbázis, valamint az
ÁNTSZ intraneten keresztül elérhető Halandósági Mutatók Informatikai Rendszere. A legismertebb nemzetközi vizualizációs programok a WHO European Health for All Database adatbázisa, a Globális Betegségteher Vizsgálat internetes oldala és az OECD Better Life Indexet bemutató oldala. Ezek sokszínúségéből is látható, hogy olyan monitorozási rendszerre van tehát szükség Magyarországon, amely képes minden egészséggel összefüggő adatgyűjtést egységes rendszerbe foglalni, minden érintett szereplővel együttmúködni és mindezen tevékenységeket hatékonyan integrálni. A Teljesítményértékelés Munkacsoport létrehozásával a 36/2013. (V. 24.) EMMI rendelet egy ilyen rendszer kialakításához keretet is biztosít. A rendszer ideálisan múködik, ha naprakész információ áll rendelkezésre a lakosság egészségéről, vagyis idejekorán jelzéseket tud küldeni a felbukkanó problémákról a döntéshozóknak. További célszerü tulajdonsága a rendszernek, hogy rugalmas és képes alkalmazkodni a szakterületeken megjelenő új kihívásokhoz. Fontos látni, hogy ez csupán szemléletmódbeli újítás, hiszen technológiai oldalról elvi akadálya mára már nem lehet egy ilyen egységes megközelítés adaptálásának. Mielőtt bemutatásra kerül a fenti kritériumoknak eleget tevő hazai egészségmonitorozási rendszer koncepciója, célszerú áttekinteni, milyen társadalmi szereplők és azok milyen hatásai befolyásolják az egészséget. ${ }^{4}$ [1. ábra] Egy egyén vagy egy közösség egészségével kapcsolatban két tényezőt célszerű külön kezelni: az egészségi állapotot és az egészségmagatartást. Bár e két elem szoros összefüggést mutat, külön-külön érik őket az egészséget változtató hatások, és különböző egészségvédő, fejlesztő és helyreállító beavatkozások irányulnak rájuk. Az egyének és a közösségek egészsége, életmódja ugyanakkor egyáltalán nem különíthető el az őket körbevevő körülményektől, azoktól a fizikai és társas környezeti sajátosságoktól, amelyek mindennapi életüket befolyásolják, és amelyek lehetőségeket kínálnak számukra az egészséges életvitelhez, szükség esetén a gyógyuláshoz. Az ábrán azonosított szereplők így a közvetlen hatásokon túl, szükségszerűen közvetetten is hatással lehetnek az életkörülmények befolyásolásával az egyének és közös-

\footnotetext{
i 2010-ben a GDP 19\%-át tette ki az egészségproblémák okozta anyagi veszteség.

ii Ilyen program volt például a 2001-ben elindított Magyar Egészségadattár (Epinfo, 9. évfolyam 13. szám, 2002. április 5.), vagy a 2010-ben induló Kapacitástérkép Tervező és Monitoring Kutató Alkalmazás fejlesztés (http://www2.gyemszi.hu/site/index.php?mid=265\&lang=hu), majd az ezt továbbfejlesztő Országos egészségmonitorozási és kapacitástérkép adatbázis és a ráépülő alkalmazások létrehozását célzó projekt (https://pulzus.aeek.hu/index.php).
} 


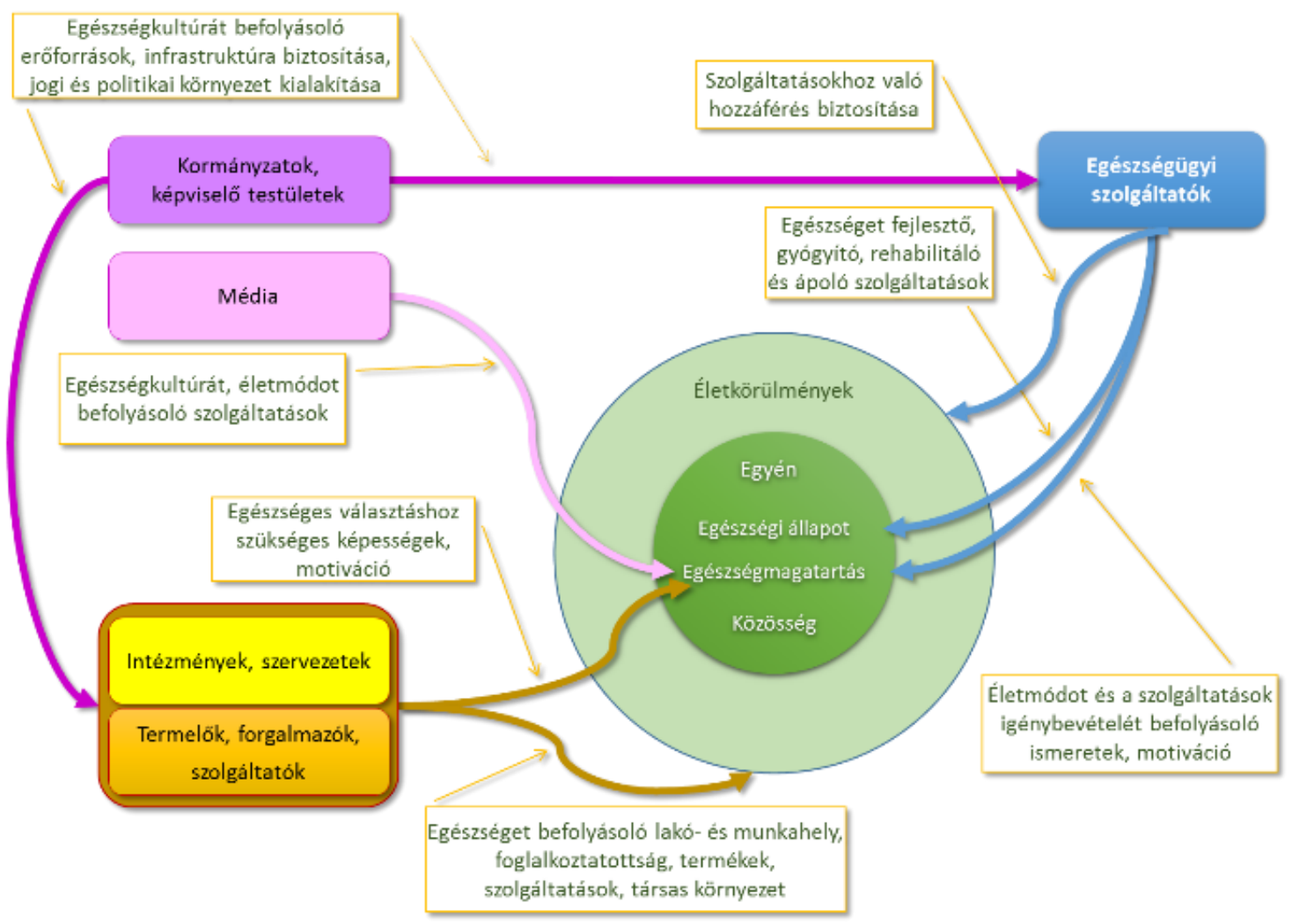

2. ábra: Adat és információáramlás a javasolt egészségmonitorozási rendszerben (Folytonos vonallal az adatokat, pontozott vonallal az információt és pontokkal szaggatott vonallal pedig az adatokat és információkat közösen jelöltük.)

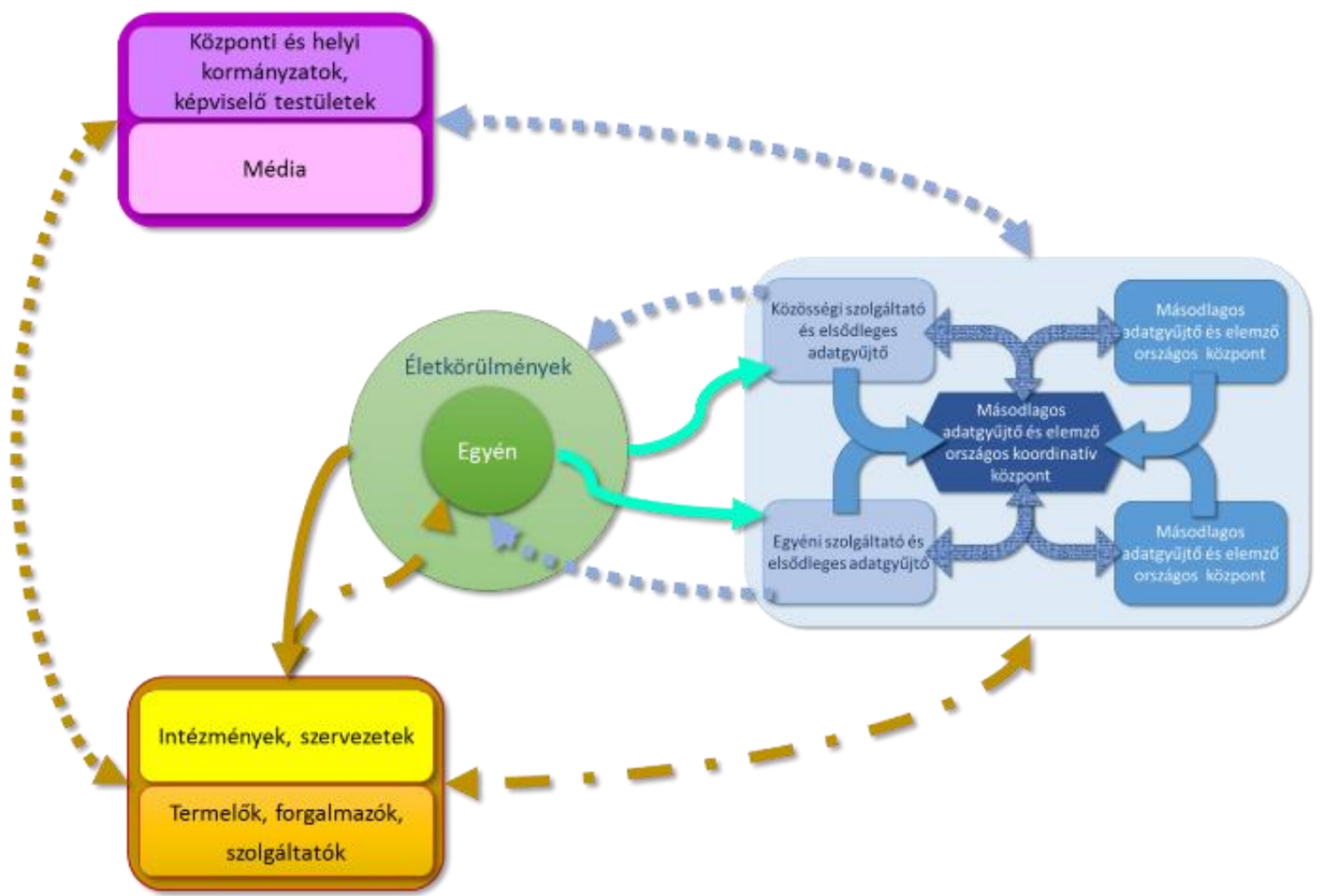


ségek egészségére. Az egészségre ható szereplők közül kiemelkedően fontos az egészségügyi szolgáltatók szerepe, amelyek szolgáltatásaikon keresztül az egyének és közösségek egészségi állapotát, egészségmagatartását és életkörülményeit is befolyásolják. Szintén fontos szereplők még a különféle intézetek és szervezetek, amelyek munkájuk révén főleg az egészséges életkörülmények, a fizikai és társadalmi környezet alakításán keresztül lehetnek hatással az egészségre. A termelők, forgalmazók, szolgáltatók többek között egészséges munkahelyek megteremtésével és az egészséges választást megkönnyítő termékek biztosításával játszhatnak szerepet a rendszerben. További szereplőként azonosíthatjuk a központi és helyi kormányzatokat és képviselőtestületeket, amelyek a megfelelő jogi, politikai, társadalmi környezet kialakításával járulnak hozzá valamennyi szereplő egészséget befolyásoló hatásához. Végül nem szabad megfeledkezni a média egészségkultúrát befolyásoló szerepéről, amely közvetetten változtatja az egyének és közösségek viselkedését. Jól látható, hogy számos tényező összetett hatása befolyásolja az egészséget, ezért olyan egészségmonitorozási rendszert célszerű működtetni, amely minél szélesebb körben, lehetőség szerint valamennyi jelentős hatást képes figyelemmel kísérni.

\section{MILYEN MAGYARORSZÁGI EGÉSZSÉGMONITO- ROZÁSI RENDSZERT JAVASOLUNK?}

Az egészséggel kapcsolatos adatok és az azok értékelésével, értelmezésével nyert információk áramlásának javasolt képét mutatja be a 2. ábra. Ennek alapján az egyén és a közösség egészségéről, életkörülményeiről az elsődleges egyéni, illetve közösségi adatgyűjtőkként és szolgáltatókként jelölt szereplők, valamint egyes for-profit és non-profit szervezetek gyűjtenek közvetlenül adatot. Minden további szereplő ezen adatokat, illetve az ezek alapján előállított másodlagos adatokat, valamint az adatok feldolgozásával nyert információkat érheti el. Az elsődleges és másodlagos adatgyűjtést valamint az elemző központok egészségmonitorozási munkáját egy országos koordinatív központ hangolja össze, messzemenően figyelembe véve az adatgyűjtésben, elemzésben részvevők, valamint az adatokat, információkat felhasználók igényeit. A másodlagos adatgyűjtő és elemző központokba tartoznak például az országos intézetek, az orvostudományi egyetemek vagy az Országos Egészségbiztosítási Pénztár. Ezek a központok az adatok gyűjtését és elemzését előzetes egyeztetés alapján, egy-egy szakterületen végzik. Így például az egyik specializáltan az egészségügyi ellátások finanszírozásával, a másik a hazai mortalitási és morbiditási helyzet értékelésével, megint másik az egészségfelmérésekkel, egy további az alkoholfogyasztással, vagy a dohányzással foglalkozik. Az egészségmonitorozási rendszer ilyen módon felosztott múködésével megszúnik a párhuzamos adatgyűjtés és elemzés, és a jelenlegi rendszerből szabadon átcsoportosítható erőforrások szabadulnak fel. Az egészséggel kapcsolatos adatgyűjtés és elemzés során az egészségmonitorozási rendszer tagjai a különböző szereplők igényeihez igazított információkat állítanak elő, amelyeket azok felhasználhatnak az egyén és közösség egészségének befolyásolásához. Ilyen szereplők például a központi vagy helyi kormányzatok, a képviselő-testületek, a média, valamint a for-profit és non-profit szervezetek jelentős többsége. Az egészséggel kapcsolatos információk azonban közvetlenül az egyénekhez és közösségekhez is visszajutnak, közérthető nyelven interpretálásra kerülnek, így számukra is biztosítottá válik a saját egészségükkel kapcsolatos informált döntéshozatal.

Kiemelendő, hogy ezek az egészségmonitorozási rendszerből származó információk megfelelő alapot biztosítanak a lakóhely-közeli egészségszolgáltatás keretében megvalósuló egyéni és közösségi egészségtervezés folyamataihoz is.

\section{AZ EGÉSZSÉGFELMÉRÉSEK ÚJ KONCEPCIÓJA}

A lakosság egészségveszteségeinek jelentős többségét a krónikus betegségek okozzák, amelyek kialakulása bizonyítottan erős összefüggést mutat az egyének egészségmagatartásával. Ezért kiemelten fontos az egészségmagatartás megváltoztatását célzó, primer prevenciós beavatkozások előkészítésének és megvalósításának támogatása, amely csak releváns és időszerű adatok birtokában lehetséges. Ennek eléréséhez a szerzők az egészségmonitorozási rendszer részeként, egy az eddigi magyar gyakorlathoz képest újszerú adatgyüjtést, egészségfelmérést javasolnak, amely nagyrészt integrálná a jelenleg 4-5 évente ismétlődő iskolai és felnőtt egészségfelméréseket (pl.: Health Behaviour in School- 
aged Children [HBSC], Európai Lakossági Egészségfelmérés [ELEF]). A következőkben ez a folyamatos egészségfelmérést lehetővé tevő módszer kerül felvázolásra. Az egyének egészségi állapotáról, egészségmagatartásáról, az azt befolyásoló tényezőkről, életkörülményeikről, egyszóval egészségkultúrájáról való információgyűjtés módszertani alapja egy újfajta, a Magyarországon eddig megszokottól eltérő lakossági egészségfelmérés.iii [3. ábra] A kérdőíves és eszközös (pl.: vérnyomásmérés, antropometriai mérések, mozgásszenzor használata, stb.) adatgyűjtés - Magyarországon innovatívnak számító - sajátossága annak időtartamában, mintaválasztásában és megvalósítóinak személyében van. Az eljárás kulcsa a folyamatos, un. gördülő mintavételi eljárás (rolling sample), ${ }^{5}$ amely képes lenne biztosítani a felmérés folytonos jellegét. Ez a folytonosság az országos lefedettséget garantáló védőnőkön, illetőleg háziorvosi praxisokon, praxisközösségeken alapulna. Ez a fajta mintavételezési eljárás nem ismeretlen az egészségfelmérések körében, évtizedek óta sikeresen alkalmazzák az Amerikai Egyesült Államokban is. Annak ellenére, hogy ezzel az eljárással egy-egy adatfelvevőnek évente csupán kevés esetet kellene teljesítenie, a folyamatosan zajló felmérés és a jelentős számú adatfelvevő részvétele miatt a jelenlegi hazai egészségfelmérésekhez viszonyítva lényegesen nagyobb esetszámot lehetne biztosítani. A várhatóan évente több tízezres mintaméret következtében a társadalmi és földrajzi jellemzők vonatkozásában a mainál sokkal részletesebb adatok állnának elő. Ilyen módon az egyegy adatgyújtőre jutó kevés esetszám mellett - azaz minimális egyéni terheléssel - is biztosítható lenne a felmérés országos reprezentativitása. A felméréssel a fóbb demográfiai jellemzőkre (életkor, nem, iskolai végzettség, településtípus), valamint a területi megoszlásra vonatkoztatott reprezentativitás mellett a szezonális nyomon-követhetőség és összehasonlíthatóság is megoldottá válna. A módszer haté-

3. ábra: Gyermekek és felnőttek folyamatos egészségfelmérésének vázlata

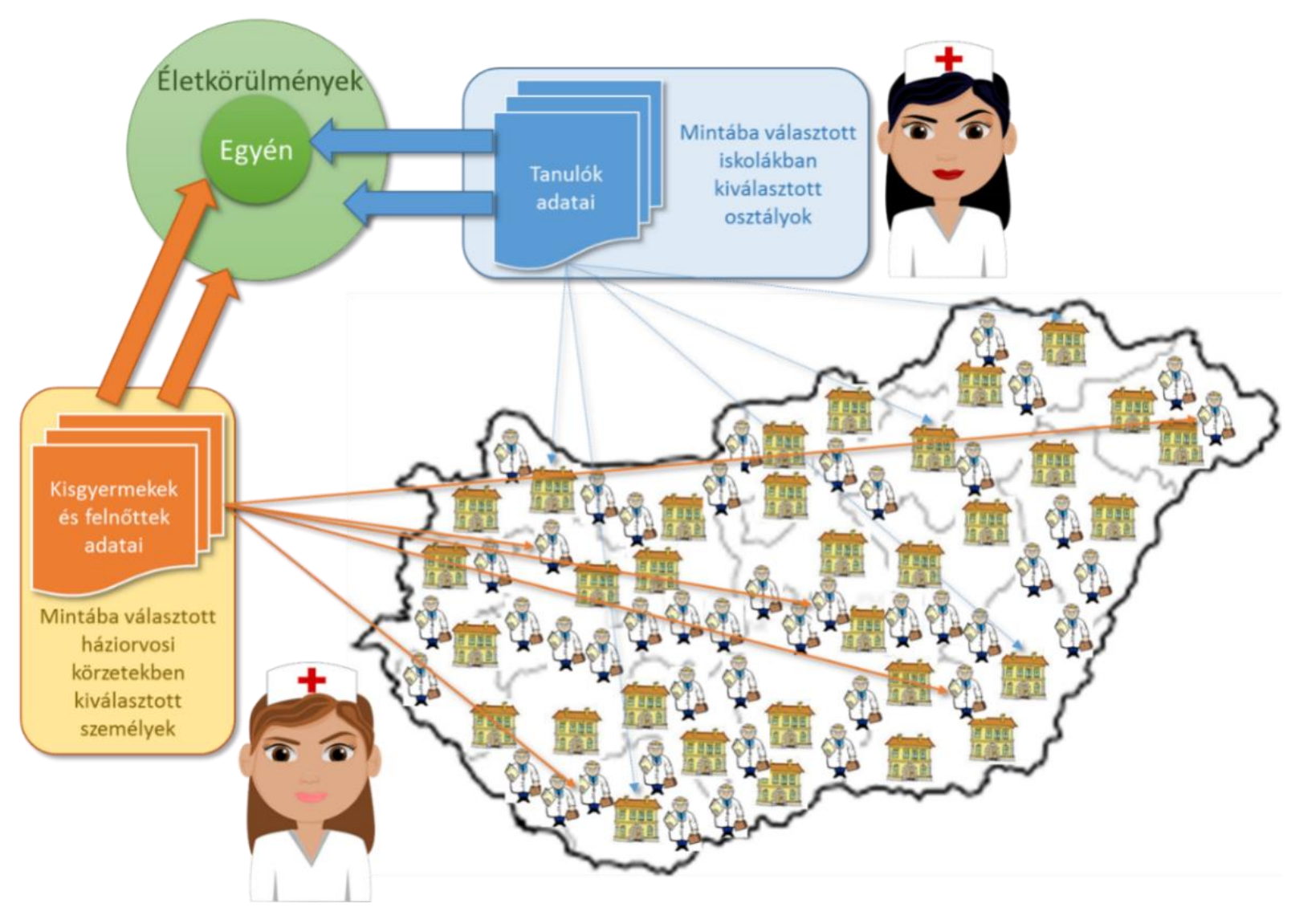

iii A Debreceni Egyetem Népegészségügyi Iskola által 1998-ban indított Háziorvosi Morbiditási Adatgyűjtés Program (HMAP) részben hasonló célokat tűzött ki: „A program célja olyan módszertan kidolgozása, bevezetése és tesztelése volt, mely megbízható és az ország lakosságára nézve kor és nem szerint reprezentatívnak tekinthető adatokat szolgáltat a legnagyobb népegészségügyi jelentőségű betegségek prevalenciájáról és incidenciájáról." (http://www.publichealth.hu/nepc.php?mlink=54\&mmid=1\&mt=0\&smid=1\&tmid=1) 
kony módon lenne képes az egészséggel kapcsolatos pozitív és negatív trendek mögött megbújó társadalmi jelenségek azonosítására is. A felmérés kiemelten fontos része a mintába kiválasztott gyermekek, osztályok védőnők általi egészségfelmérése, hiszen így a fiatalok egészségmagatartásáról és egészségkultúrájáról is naprakész, releváns, a beavatkozásokhoz jól használható adatok válnának elérhetővé. [Részletesebben lásd a két példát a közlemény végén a Hogyan támogathatná az új koncepció szerint múködő egészségfelmérés a vashiányos vérszegénység és az e-cigaretta használat visszaszorítását? (elképzelt esetek) című írásban.] A lakóhelyközeli egészségfelmérés folyamatossága és a gördülő mintavételezés biztosítaná, hogy az egészségmagatartásról időszerű, folyamatosan frissülő adatok álljanak rendelkezésre, amelyek lehetővé tennék az elemzés során detektált problémákra való gyors reagálást. Megfontolandó, hogy egy-egy fontos társadalmi-gazdasági kérdés megválaszolása érdekében egy-egy kiválasztott társadalmi csoport kisebb almintáján ismételt adatfelvétel történjen, és így - akár időszakosan is - követéses vizsgálat is elvégezhető lenne.

\section{MEGBESZÉLÉS}

A bemutatott egészségmonitorozási rendszer egyes, jelenleg is meglévő elemek integrálásával egy új és hatékonyan múködő struktúrát alakítana ki. Ennek a felépítésnek az előnye, hogy időszerű, aktuális információkkal segítené az informált döntéshozatalt, amely csökkentené az egyes döntések politikai kockázatát. Egy ilyen rendszerben nemcsak egyéni, közösségi, hanem országos szinten is értékelni lehet az egészséget, így megfelelő információkat lehet szolgáltatni az országos egészségtervezéshez, vagyis az ágazati stratégia elkészítéséhez. A rendszer eredményeképpen az egyes beavatkozások jobban tervezhetővé válhatnának, az intézkedések hatása pontosabban becsülhető lenne, és a Magyarországon sok tekintetben elhanyagolt intézkedések hatásvizsgálata is megoldódna. Olyan rendszer épülhetne ki, amely társadalmi és földrajzi dimenziók mentén is részletezett releváns képet adhatna a magyar lakosság aktuális egészségi állapotáról. A bemutatott rendszer az egyének egészségi állapotának folyamatos monitorozásával, a változások nyomon követésével korai jelzőrendszerként képes a megjelenő egészségproblémákat idejekorán detektálni és ezeket az illetékes szervezetek, intézmények, lakóhely-közeli egészségügyi szolgáltatók számára jelezni.

Hangsúlyozni kell, hogy a problémákra adott válaszokban, beavatkozások kiválasztásában és megvalósításában az egészségmonitorozási rendszernek nincs közvetlen szerepe. Az egyes beavatkozások megfelelő megbízhatóságú ok-okozati hatásvizsgálatának kivitelezése is túlmutat a rutinszerű egészségmonitorozás hatáskörén. Ilyen jellegű kutatások külön erre a célra kiképzett munkaerőt, jelentős pénzügyi erőforrásokat és hosszú időt igényelnek, mint ahogyan azt például az 1948-ban indult, és ég ma is tartó Framingham Heart Study példáján is láthatjuk. Ilyen vizsgálatokat Magyarországon csak különösen indokolt esetben érdemes végezni, erre elkülönített erőforrások felhasználásával. A mindennapokban ezért az egészségmonitorozás során detektált problémák megoldására olyan nemzetközi szinten jó gyakorlatként bevált beavatkozásokat javasolt átvenni és adaptálni, amelyek bizonyítottan hatásosak, ezért ezek átvétele esetén többnyire nincs szükség Magyarországon hasonló vizsgálatra. Ez fordult elő például a biztonsági öv kötelező használatát célzó hazai beavatkozások esetében is, azaz nem történtek hazai vizsgálatok, hiszen más országok vizsgálatai és tapasztalatai biztosították a beavatkozás hatásosságát. Az így adaptált beavatkozások hatását tehát az egészségmonitorozási rendszer nem vizsgálja, azonban eredményességét a folyamatos adatgyújtéssel és elemzéssel nyomon követi és a probléma fennmaradását vagy megszúnését detektálhatja. Az egészségmonitorozási rendszer ilyen újfajta felépítéséhez és múködéséhez jól kapcsolódnak az elmúlt évek során a szakterületen tapasztalt informatikai fejlesztések is, mint például a jelenleg tesztelés alatt álló, hamarosan bevezetésre kerülő Elektronikus Egészségügyi Szolgáltatási Tér (EESZT), amely a megfelelő egészségmonitorozáshoz is elkerülhetetlen egészségügyi ágazaton belüli folyamatos, költséghatékony kommunikációt hivatott biztosítani. A hasonló jövőbeli fejlesztések hatékonyabb ágazaton belüli és ágazatközi elterjedését segítheti a fentebb vázolt egészségmonitorozási rendszer központi koordináló szereplője, a többi résztvevő számára biztosított folyamatos szakmai támogatással. A bemutatott rendszer felépítéséből következik, hogy a technológiai újításokkal párhuzamosan képes fejlődni, valamint mind az adatgyújtés 
területén, mind az adatelemzésnél a legújabb technológiákat és módszereket (mint például a rendszertudományi megközelítések) képes használni. Az egységes adatgyűjtés eredményeként idővel olyan mennyiségú és minőségű adatok állnak majd rendelkezésre, amelyek lehetővé teszik jövőbeli történések, forgatókönyvek szimulációját is. Ezek a tulajdonságok biztosítják a rendszer rugalmasságát és folyamatos alkalmazkodóképességét annak érdekében, hogy gyors és hatásos válaszokat tudjon adni a múködése közben azonosított problémákra. A magyar egészségi adatokból, illetve az azokból következő gazdasági mutatókból jól látszik, hogy nagy szükség van egy megfelelően múködő egészségmonitorozási rendszerre, nemcsak közvetlenül a döntéshozók támogatása érdekében, hanem - a rendszer hatásainak visszacsatolása révén - a lakosság egésze, az ország jövője szempontjából is. Ehhez azonban az szükséges, hogy a modern kor kihívásai- nak is megfelelő, gazdaságosan múködtethető rendszer álljon múködésbe. Az előzőekben egy ilyen rendszer felépítése és legfőbb feladatai kerültek vázlatosan bemutatásra. A szerzők remélik, hogy a következő években ez valósággá válik, és megvalósul az, amit már 1999-ben is jövendöltek a szakemberek: „Várhatóan néhány éven belül a kor színvonalának megfelelő, az egészségpolitika számára értékes információkat szolgáltató egészségmonitorozó rendszer fog múködni az országban.

\section{KÖSZÖNETNYILVÁNITTÁS}

A szerzők köszönetet mondanak Dr. Vokó Zoltánnak és Dr. Lantos Zoltánnak a kézirat elkészítése során nyújtott szakmai segítségért és támogató kritikákért.

Hogyan támogathatná az új koncepció szerint müködő egészségfelmérés a vashiányos vérszegénység és az e-cigaretta használat visszaszorítását? (elképzelt esetek)

A következőekben az egészségmonitorozási rendszer múködése, az egészségfelmérések kivitelezése kerül bemutatásra példákon keresztül. A példákban szereplő adatok természetesen az aktuális célok és a megvalósíthatóság függvényében változtatandók.

\section{Vashiányos vérszegénység visszaszorítása}

Korábbi táplálkozási vizsgálatok eredményei és a szomszédos országok tapasztalatai is arra utalnak, hogy a gyermekkori vashiányos vérszegénység komoly probléma lehet Magyarországon. A betegség hazai helyzetére vonatkozóan csupán hiányos adatok állnak rendelkezésre az egészségügyi ellátók és szolgáltatók adatbázisában, ezért az egészségmonitorozási rendszer irányítói úgy döntenek, hogy a probléma mértékét az országban valamint a társadalmi csoportok közötti megoszlását, a kisgyerekek és az iskolások táplálkozási szokásait kérdőívvel és ahhoz kapcsolódó vérvizsgálattal mérik fel. A földrajzi és társadalmi rétegek szerint reprezentatív, véletlen mintába került 10 évnél fiatalabb gyermekek családjait védőnők keresik fel, és kérdőívet vesznek fel a gyermek étkezési szokásairól. A kérdőív kitöltésére önállóan is képes, mintába került osztályok diákjaival - például a 4., 6., 8. és 10. évfolyamos tanulókkal - iskolai védőnők egy-egy tanórán töltetnek ki kérdőívet. A monitorozásra felkészített 500 területi védőnő a vizsgálat első évében szeptembertől júniusig kéthavonta 3-3 családot keres fel és vesz fel kérdőívet, a vizsgálathoz vérvétel azonban csak minden 3. gyermeknél történik. Ilyen módon a 10 évesnél fiatalabb gyermekről egyetlen év alatt mintegy 7500 kérdőíves és 2500 vérvizsgálati adatot tudnak gyújteni. 
Az ugyancsak erre a vizsgálatra felkészített iskolai védőnők - a szokásos kétévenkénti iskola-egészségügyi vizsgálat kiegészítéseként az adott évben egy alkalommal - 500 iskolában, a 4 évfolyam mintába kiválasztott egy-egy osztályában vesznek fel önkitöltős kérdőíveket, továbbá minden 10. kérdőívet kitöltő tanulótól vérmintát is vesznek. Egy év alatt, 20 fős átlagos osztálylétszámmal számolva 40000 kérdőívet és 4000 vérmintát gyűjtenek ilyen paraméterek mellett. (Összehasonlításképpen a négyévente ismételt HBSC vizsgálat tervezett mintamérete kevesebb, mint 10000 szokott lenni.) A területi védőnők felmérésre történő felkészítése egy másfélnapos továbbképzésen való részvételt, a felmérés pedig családonként legfeljebb 2 óra elfoglaltságot jelent, ami utazási idővel együtt évente legfeljebb 80 órát tesz ki egy-egy védőnőre számítva. Az iskolai védőnőkre hasonló kalkulációval kevesebb, mint 30 óra éves elfoglaltság jön ki. A felmérés során nyert adatok elemzésére az egészségmonitorozási rendszer egy kijelölt, releváns szakértőkkel - pl. gyermekgyógyászokkal, dietetikusokkal - együttmúködő elemzőközpontjában kerül sor. Az elemzés során azonosított problémákat a központ bemutatja az illetékes szervezeteknek (pl. minisztériumok, táplálkozásért vagy egészségfejlesztésért felelős országos intézetek, stb.), amelyek ezek alapján dolgozzák ki a probléma megoldását célzó intézkedésüket, például a közétkeztetés szabályozására vonatkozóan. Fontos azonban kiemelni, hogy az elvégzett kérdőíves és eszközös felméréssel nem csupán a vashiányos vérszegénységre vonatkozóan, hanem a gyermekek egészségére, egészségmagatartására, az azt meghatározó családi, iskolai környezetre, összességében az őket körülvevő egészségkultúrára vonatkozóan is releváns kép nyerhető. Így például megbízható és részletes információ állna rendelkezésre a gyermekkori elhízás, dohányzás, alkohol és drogfogyasztás gyakoriságának területi és a család társadalmi helyzete szerinti megoszlásáról is.

\section{E-cigaretta használat visszaszoritása}

Manapság az e-cigaretta használat a szakmai és össztársadalmi érdeklődés középpontjába került, azonban használatának mértékéről, céljáról nem áll rendelkezésre megbízható adat Magyarországon, így az ezzel kapcsolatos szakmai döntések is csak ezek hiányában születhetnek. Az egészségmonitorozási rendszer irányítói ezért úgy döntenek, hogy folyamatos egészségfelméréssel gyűjtenek adatot az e-cigaretta használat mértékéről, okairól valamint földrajzi és társadalmi megoszlásáról. Ennek érdekében 1000 háziorvosi praxisban kéthavonta 5, véletlen mintavétellel kiválasztott felnőttel készítenek kérdőíves interjút, azaz egy év alatt 30000 felnőtt dohányzási szokásairól nyernek információt. (Összehasonlításként, a KSH által ötévente végzett ELEF mintamérete nem éri el a 10 000-et.) Ez a tevékenység minden interjút készítő nővér munkaidejének átlagosan 5\%-át teszi ki, hiszen beleszámítva a másfélnapos továbbképzést és az utazási időket is csupán valamivel több, mint 100 munkaórát vesz igénybe az egészségfelmérés. Ezzel a módszerrel országos szinten is megbízható adatok állnának rendelkezésre az e-cigaretta fogyasztásával kapcsolatban, azonban a felmérésben részt vett személyek egyéb egészségkultúrával kapcsolatos jellemzői is megismerésre kerülnének. Az összegyújtött adatokat az egészségmonitorozási rendszer dohányzás szakterületért felelős elemző központja elemzi és interpretálja az illetékes szervezeteknek (pl. minisztériumok, dohányzás visszaszorításáért felelős országos intézmény, stb.), amelyek az e-cigaretta használat megoszlásának, a dohányzásleszokásban betöltött szerepének pontos ismeretében kezdhetik meg a szükséges döntések, beavatkozások tervezését.

\footnotetext{
${ }^{1}$ Egészségjelentés2015, Nemzeti Egészségfejlesztési Intézet, 2015, Budapest; 39. o.

${ }^{2}$ Vitrai J, Vokó Z: A hazai egészségmonitorozás lehetséges szerepe az egészségügyi rendszer teljesítményének mérésében és alkalmazásának aktuális problémái. Egészségügyi Gazdasági Szemle. 2012; 2:33-36.

${ }^{3}$ Vokó Z, Vitrai J, Ursicz G, Lépes P: Egészségmonitorozás Magyarországon a XXI. században. Mit, miért, hogyan?. Népegészségügy. 1999; 1:28-33.

${ }^{4}$ Csizmadia P, Varsányi P, Ferencz M, Vitrai J: Az egészségbarát viselkedést befolyásoló hatásháló. Egészségfejlesztés. 2014; 5-6:10-14.

${ }^{5}$ L Kish: Rolling Samples and Censuses. Survey Methodology. 1990;16:63-79.
} 